\title{
MASTERING
}

\section{BACKGROUND TO BUSINESS}


Astronomy

Australian History

Background to Business

Banking

Basic English Law

Basic Management

Biology

British Politics

Business Communication

Business Law

Business Microcomputing

Catering Science

Chemistry

COBOL Programming

Commerce

Computer Programming

Computers

Data Processing

Economic and Social History

Economics

Electrical Engineering

Electronics

English Grammar

English Language

English Literature

Financial Accounting

French

French 2
German

German 2

Hairdressing

Italian

Italian 2

Japanese

Keyboarding

Marketing

Mathematics

Modern British History

Modern European History

Modern World History

Nutrition

Office Practice

Pascal Programming

Physics

Practical Writing

Principles of Accounts

Restaurant Service

Social Welfare

Sociology

Spanish

Spanish 2

Spreadsheets

Statistics

Statistics with your Microcomputer

Study Skills

Typewriting Skills

Word Processing 


\section{MASTERING}

\section{BACKGEROUND TO}

\section{BUSINESS}

TERRY PRICE

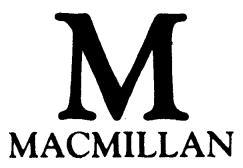


(C) Terry Price 1983, 1989

All rights reserved. No reproduction, copy or transmission of this publication may be made without written permission.

No paragraph of this publication may be reproduced, copied or transmitted save with written permission or in accordance with the provisions of the Copyright Act 1956 (as amended), or under the terms of any licence permitting limited copying issued by the Copyright Licensing Agency, 33-4 Alfred Place, London WC1E 7DP.

Any person who does any unauthorised act in relation to this publication may be liable to criminal prosecution and civil claims for damages.

First published by Pan Books Ltd as Background to Business in the Breakthrough series in 1983.

Fully updated and revised edition first published 1989 by

MACMILLAN EDUCATION LTD

Houndmills, Basingstoke, Hampshire RG21 2XS

and London

Companies and representatives

throughout the world

Typeset by TecSet Ltd., Wallington, Surrey.

British Library, Cataloguing in Publication Data

Price, Terry, 1938-

Mastering Background to Business

1. Business practices

I. Title

650

ISBN 978-0-333-48802-7

DOI 10.1007/978-1-349-19833-7

ISBN 978-1-349-19833-7 (eBook)

ISBN 978- 0-333-48802-4 Pbk

ISBN 978- 0-333-48803-2 Pbk export 
Acknowledgements

viii

Introduction

ix

1 Goods and services

1.1 Goods and services

1.2 Changes in consumer expenditure

1.3 Primary, secondary and tertiary production

1.4 The working population

2 Business

2.1 Sole trader

organisation

2.2 Partnerships

2.3 Limited companies

2.4 A public company

2.5 Public enterprises

2.6 Other types of business organisation

3 Internal

3.1 The Board of Directors

organisation of

3.2 The Company Secretary

42 companies

3.3 The Managing Director

3.4 Internal communications

4 Marketing and

4.1 Market research and advertising product planning

4.2 Promotion of the product

4.3 After-sales service

4.4 Marketing 
5 Distribution retailing, wholesaling and other markets

6 Finance

7 The Stock Exchange

8 Insurance and business insolvency

9 Banking services and business

10 Personal finance

11 Transport and communications

12 International trade
$5.1 \quad$ Retailing 65

5.2 Wholesaling 80

5.3 Other markets 84

6.1 Balance sheets, and profit and loss accounts 88

6.2 Expansion of the business 93

6.3 Company finance 96

6.4 How a company obtains additional finance $\quad 98$

7.1 How shares change hands on the Stock Exchange

7.2 The Big Bang and Stock Exchange changes

7.3 The importance of the Stock Exchange

8.1 Insurance 107

8.2 Business insolvency

9.1 Functions of the bank

9.2 Types of account 125

9.3 Cheques

9.4 Methods of payment using the bank

9.5 Bank credit

10.1 Borrowing 138

10.2 Lending 146

10.3 Investment management 150

11.1 Transport

11.2 Communications and new technology

12.1 Balance of Payments

12.2 Protection and free trade 
12.3 Exporting

12.4 Importing

12.5 Trading blocs

175

13 Trading documents 13.1 The Letter of Enquiry 178

13.2 The Quotation 179

13.3 The Order 180

13.4 The Acknowledgement 181

13.5 The Advice Note 182

13.6 The Delivery Note 182

13.7 The Invoice 183

13.8 Value Added Tax 184

13.9 Credit Notes and Debit Notes 185

13.10 Statement of Account 185

14 Consumer protection

15 Business and the government

\section{Taxation}

14.1 Rights under the Sale of Goods Act $1979 \quad 188$

14.2 Trade Descriptions Act 1968 and 1972

14.3 Other Acts of Parliament which protect the customer 191

14.4 Other protection 192

14.5 Consumer credit 192

14.6 Other types of credit 194

15.1 Monopolies and restrictive practices 199

15.2 Government aid to industry 200

15.3 Planning permission 201

15.4 Employment and the government 202

15.5 Health and safety 204

16.1 Direct tax 206

16.2 Indirect taxes 210

16.3 Other forms of government revenue $\quad 212$

16.4 Summary 216

Answers to Exercises 218

Index 


\section{ACKNOWLEDGEMENTS}

To:

John Meed and Tim Burton of the National Extension College for their many helpful comments.

Keith Martin and Anne Bown for their help with the chapter on Distribution.

John Paget and Susan Bennett, librarians at Canterbury College of Technology, for their valuable assistance in obtaining up to date information on the business environment.

David Hogg, Senior Technician at Canterbury College for all his assistance.

Ian Cooke, Chief Accountant, Canterbury City Council, for his help with aspects of local taxation.

The Halifax Building Society, Barclays Bank and the Midland Bank for their assistance with building society and banking matters.

Pat Roberts who assisted with some of the typing and editing.

Finally to my wife Sheila whose help and encouragement made it possible for me to complete this book.

The author and the publishers acknowledge and thank the following companies and organisations for allowing the use of illustrative material: Access (Midland Bank), Barclay Card, The Burton Group, Canterbury City Council, General Motors Acceptance Corporation, Lufthansa, Marks \& Spencers Charge Card, Midland Bank, NEC and Storecard Ltd. 


\section{INTRODUCTION}

How to use this book. Throughout the book you will find questions which you are encouraged to answer before reading on. There are two types of question sections: exercises and activities.

Exercises Usually short questions requiring quick answers. They either help to prepare you for the text which follows, or they provide a means for you to test yourself whether you have understood a particular principle or technique. Answers can be found at the back of the book. It is obviously best for you to try to answer the question before reading on, but, whether you think you have got it right or wrong, read the answer before moving on to the next topic. If you have somehow made a mistake the answer will usually tell you where you might have gone wrong. Exercises placed at the end of a chapter or at the end of a section are intended to review your understanding of several principles or techniques. You can, of course, 'cheat' and read the whole book from beginning too end without attempting to answer the questions at all. But if you do, there is only one person you are cheating. Guess who?

Activities Again, designed to test your understanding of the text, but they usually ask you to use some information which you will not find in the text. To answer these questions you have to use your own experience or discover some fresh facts for yourself. Sometimes an activity is simply an opportunity for you to stop and think about an important point raised in the text.

This book describes the situation as it exists in 1988. Remember that the business world is a changing environment and throughout the book readers are encouraged and given ideas on how to keep up to date. 
To Sheila 